\title{
Información
}

\section{Bancos de imágenes para el patrimonio}

\section{Lola Cuenca}

Doctora en Ciencias de la Información

Gestora de Patrimonio Cultural

Profesora de Comunicación Audiovisual en UCM y UPV

Los Bancos de Imágenes, que nacieron con el desarrollo de la moderna publicidad, están creciendo en la consideración de su utilidad para la creación de archivos en Centros de Documentación, que suministren información privilegiada para llevar a cabo procesos de investigación, de restauración, de rehabilitación, de difusión y de comunicación sobre los fondos de Arte y Cultura universales.

\section{Arte en internet}

Se ha puesto de moda recientemente -y por razones de la más rabiosa actualidad- hablar del ADN. Aunque la aplicación de esta tecnología se connota con el ser humano, habría que ir estableciendo algo similar para las obras de arte. Y la red puede contribuir en gran medida a erradicar la identidad de obras desaparecidas, pues un S.O.S. icónico puede valer por mil palabras. Conocemos la existencia de un Museo Imaginado, que a partir de una excelente idea original, pretende dar a conocer a través de Internet la relación de obras de arte del Patrimonio Español desaparecidas en circunstancias no demasiado clarificadas y relacionarlas a través de un catálogo razonado puesto a disposición de la policía especializada, a través de la Interpol.

Para ello habría que crear un Banco de Imágenes digital específico, con las correspondientes fichas explicativas de los curricula a partir de su creación, época, estilo, autor, técnicas empleadas, incidencias a tener en cuenta, propietarios, museos, etc., con objeto de facilitar las pesquisas sobre los trayectos recorridos por las obras de arte desde su desaparición hasta la actualidad.

Uno de los más originales trabajos de investigación relacionados con un episodio histórico decisivo en el devenir del conflictivo siglo XIX hispánico es el que nos acerca a la búsqueda de los paraderos de obras de arte de nuestro patrimonio cultural, a partir del expolio realizado por la ocupación napoleónica en España y de los posteriores saqueos y destrucciones sufridos durante el período de nuestra guerra civil y la segunda conflagración mundial, que dio lugar a la desaparición de valiosas propiedades artísticas de los judios perseguidos y, posteriormente, de la requisa por parte de los vencedores del patrimonio de museos oficiales y de algunas ricas colecciones privadas de arte.

\section{El Museo Imaginado}

Con el título de "El Museo Imaginado", su autor, Federico García Serrano, propone la creación virtual de este museo, que recogería en sus salas "imaginarias" los cuadros y pinturas rescatados del olvido, presentes ahora de nuevo en la memoria recuperada por los investigadores. Para ello elegiría una reconstrucción por ordenador del antiguo Alcázar madrileño de los Reyes Cristianos.

Se trata del proyecto MUSIMA ${ }^{1}$, como así lo bautiza su autor, que a través de la constitución de un Centro de Documentación Virtual, procedería al estudio y catalogación de la pintura española perdida y expoliada, organizando el museo virtual por salas, clasificadas por estilos y cronologías, con imágenes de referencia y las correspondientes reseñas bibliográficas para la elaboración de las oportunas fichas.
Esta peculiar aventura cultural cuenta con una propuesta bien estructurada en cuanto al Centro de Documentación Virtual, cuyo objetivo de mantener permanentemente actualizada una Base de Datos Multimedia, de acceso a través de Internet, ofrece ya más de seis mil registros y casi dos mil imágenes contenidas en el CD-ROM aludido. Datos más que suficientes para reemprender la casi utópica tarea de confeccionar un Catálogo General de la Pintura Española fuera de España. Obligada es la referencia al catálogo que en su día realizara el investigador e historiador de arte, Juan Antonio Gaya Nuño, que contiene datos de inapreciable valor para este proyecto.

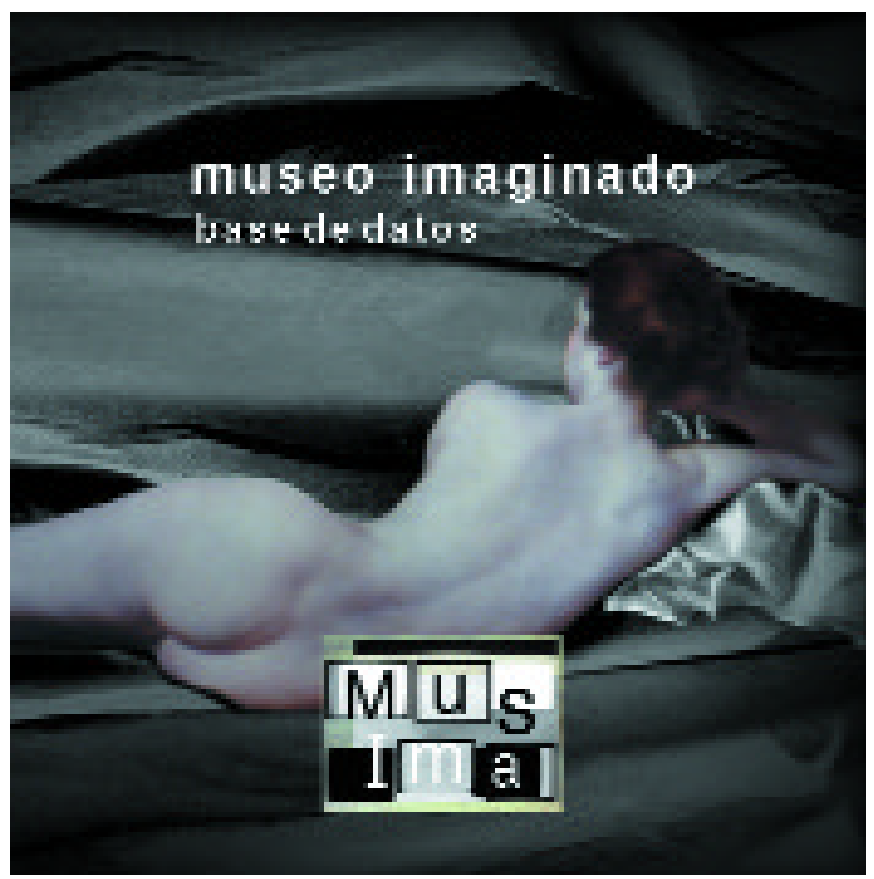

INAE

Nuestro país es un inmenso poseedor de riquezas artísticas y el investigador, al transferirse las competencias a las Comunidades Autónomas, se las ve y las desea para poder tener acceso a tan disperso patrimonio. Sería de desear -y no hemos citado los archivos de imágenes de las televisiones- seguir el ejemplo del pais vecino, que se dotó del INA (Instituto Nacional del Audiovisual) para unificar el archivo y documentación de las imágenes visuales y sonoras producidas por los media TV. De ahí, que al estilo de una poderosa Biblioteca Nacional, reivindiquemos la creación de otro no menos poderoso archivo y centro de documentación de imágenes: el Instituto Nacional Audiovisual Español².
${ }^{1}$ http://www.museoimaginado.com

${ }^{2}$ CUENCA, Lola, Bancos de Imágenes (Investigación, conservación y difusión del Patrimonio Cultural), III.3.7.1. INA, pp. 356-362, Tesis Doctoral (inédita), UCM, Madrid 2000 